\section{Gorbachev demands more effort}

SoviET science can expect in the next five years the kind of shake-up which $\mathrm{Mr}$ Mikhail Gorbachev's administration has already launched in other sectors of the economy. In his marathon six-and-a-half hour keynote speech to the TwentySeventh Party Congress last week, Mr Gorbachev promised Soviet scientists an improved material-technical research base and the creation of "conditions for fruitful activity". In return, he said, the country has the right to expect "discoveries and inventions which ensure genuinely revolutionary changes in the development of technical science and technology". But in many cases, the application of research is being blocked by "the ambitions of individual groups of scientists, departmental hostility towards the inventions of others, and a lack of interest from the production sector".

Particular targets of Mr Gorbachev's criticisms were the research institutes that belong neither to the academy network nor to the higher education sector, but come under various ministries. Last June, at the plenary meeting of the Party Central Committee, Mr Gorbachev pointed out that these institutes had proliferated over the past 20 years more as a means of enhancing the prestige of individual ministries than from considerations of useful and necessary research.

Last year's meeting urged the absorption of such institutes into inter-industrial scientific complexes, cutting across existing ministerial boundaries, but not everyone is in favour of such a move. "We must find out who is opposing it", Mr Gorbachev warned.

The universities and institutes of higher education could also do better, Mr Gorachev said. More than 35 per cent of Soviet scientists and pedagogic workers are concentrated in the higher education sector, as are almost half of all persons with a Doctor of Sciences degree. Yet only 10 per cent of Soviet research is conducted in the universities. Proposals should be worked out for strengthening ties between the universities and production, in such a way as to take into account the training of the next generation of scientists.

The Academy of Sciences escaped fairly lightly - indeed, at one point, it was even praised for having established a new department of information science and computer technology. But it was instructed fairly sharply to "pay more attention to fundamental research" and to its implementation. That, Mr Gorbachev said, is the "sacred duty" of every scientist, engineer, designer and enterprise director.

Parallel with an intensified research programme, Soviet industry is to be massively re-equipped on a "science- intensive" basis. Capital investment in industry over the next 10 years will be 200,000 million roubles more than in the preceding decade. Widespread "electronization" (apparently a neologism of $\mathrm{Mr}$ Gorbachev's own coining) and integrated automation of industry is planned, also the production on an industrial scale of software for computers and control systems. Furthermore a major drive is envisaged against delays in the construction and modernization programmes which have tied up enormous investment resources and slowed down the rate of technical progress.

Academician Anatolii Aleksandrov, president of the Soviet Academy of Sciences, replied, as it were, on behalf of the scientists. After a virulent polemic against the United States he offered a cautious defence of the research sector. The academy, he said, is concentrating, as Mr Gorbachev would wish, on both fundamental
POLAND should establish a network of inter-university laboratories with "unique" equipment, according to Politburo member Tadeusz Porebski. Addressing a plenary meeting of the Central Committee of the Polish United Workers' Party last month, Porebski said that, however inconvenient the use of such facilities might be, there was no other way for Poland to provide the higher education sector with research equipment. The lack of hard currency makes it impossible, he said, to supply all the universities with the equipment they claim to need.

The plenum was convened to formulate party policy on education and youth what party leader General Wojciech Jaruzelski called "the battle for the minds and hearts of young people". The major part of the discussion was therefore devoted to ideological matters such as the need to strengthen the compulsory university courses in Marxism-Leninism, and the low rate of party membership among students and junior academics. It proved impossible, however, to discuss the ideology of education without dealing with the overall problems facing Polish education.

Higher education, it was admitted, receives insufficient help both from the government departments concerned with the economy and from the production sector which looks to it for a supply of skilled graduates. Investment in education has been increasing over the past five years, reaching, it was claimed, 4.5 per cent of the national income in 1985 (for the entire and applied projects which could be implemented in production, but which, in fact, are not being implemented because of bureaucratic problems.

Soviet science, said Aleksandrov, has now reached a strong position in all the main branches of science - biology (where it has made up its former grave deficits), biochemistry, electronics and microprocessor technology. But because of the probiems of reaching an agreement with "far too many ministries", it is difficult to work properly.

"Look", he urged the Congress, "at Comrade V. A. Kotel'nikov, sitting here in this hall", who worked out an optical fibre communications system, only to have it rejected by industry because too many ministries would be involved. But now a production complex is being organized, and soon things will be moving in the right direction. For there is no greater grief to a scientist, Aleksandrov concluded, than when he sees the work he has completed, which he knows to be necessary and useful, simply lying inactive on the shelf.

Vera Rich

\title{
Winning hearts without books
}

educational sector). But an annual expenditure of at least 5 per cent of national income is needed to prevent deterioration of the existing situation, and if the educational system is to be modernized, 7 per cent of national income will be required. The production of textbooks and educational aids (including computers) is way behind schedule, and an "incorrect personnel policy" has led to a lack of job mobility among younger academics, in sharp contrast to the national economy as a whole, where the high job turnover is a source of anxiety to the planners.

Some of the proposals at the congress had both economic and political implications. Postgraduate research in Poland was very considerably curtailed in 1982 , and it is now suggested that doctoral studies should be built up by sending more Polish postgraduates to study in other socialist countries, especially the Soviet Union, Czechoslovakia and East Germany. Research funding should give priority to the subjects specified by the integrated Comecon research plan worked out in Moscow last December. And, in spite of repeated pledges by the Minister of Science and Higher Education, Dr Benon Miskiewicz, that no political purge of academics is being planned, the party view, as expressed by General Jaruzelski, was somewhat different. When it comes to the promotion of university lecturers, he said, the essential criteria must include the "ethical and political stance" as well as their scholarly and pedagogic talents.

Vera Rich 